\title{
Assessment of the bacterial diversity in fenvalerate-treated soil
}

\author{
H.F. Luo, H.Y. Qi and H.X. Zhang* \\ Department of Environmental Biotechnology, Research Center for Eco-Environmental Sciences, Chinese Academy of \\ Sciences, P.O. Box 2871, Beijing 100085, China \\ *Author for correspondence: Tel.:+86-10-6284-9156, fax:+86-10-6284-9155, E-mail: hxzhang@mail.rcees.ac.cn
}

Received 3 July 2003; accepted 16 December 2003

Keywords: Bacterial community, colony morphology, DGGE, diversity, fenvalerate

\section{Summary}

The impact of the pesticide fenvalerate on the diversity of the bacterial community in soil was investigated in this study. After treatment with $0.1,0.5$ or $1.0 \mathrm{mg}$ fenvalerate $\mathrm{g}^{-1}$ soil in three soils and incubation for a 40 -day period, the changes in diversity were monitored by two different methods. The cultivable heterotrophic diversity was investigated by colony morphology on solid LB medium. Genetic diversity was measured as bands on denaturing gradient gel electrophoresis (DGGE) gels by total genomic DNA extraction and purification, PCR-amplification of bacterial 16S rDNA fragments. The Shannon-Wiener index of diversity $(H)$, richness $(S)$ and evenness $\left(E_{H}\right)$ were used to measure changes in the bacterial community in the soils. The results of the cultivable heterotrophic diversity and genetic diversity showed that there was an obvious decrease in diversity due to the application of fenvalerate to the soils, and the different amounts added had different impacts on the diversity. Bands appearing to be either enhanced or inhibited as a result of the fenvalerate treatments were excized and sequenced. Sequencing of excized DGGE bands indicated that application of fenvalerate had an obvious impact on several Pseudomonas spp., or Xanthomonas campestris or Streptomyces avermitilis. This revealed that microbial community changes can occur due to the application of fenvalerate to soil.

\section{Introduction}

Fenvalerate $[(R S)-\alpha$-cyano-3-phenoxybenzyl $(R S)$-2-(4chlorophenyl)-3-methylbutyrate] (Figure 1), is an insecticide belonging to the group of synthetic pyrethroid insecticides. It is used worldwide to control a wide range of pests in agriculture and for insect control in homes and gardens and on cattle. Although it is widely used for control of the cotton bollworm, Helicoverpa armigera (H.) in China, there is a serous lack of information on the effect of this kind of pesticide on the soil community. As increasing interest in the field of microbiological ecology has focused on changes in microbial communities as a response to environmental stress in recent years, it has become necessary to examine these aspects experimentally.

Before the development of molecular techniques for estimation of genetic diversity, investigations of this kind were restricted to cultivation-based methods in which only the aerobic heterotrophic bacterial population capable of forming colonies on solid media could be examined. These methods cannot reflect the original composition of the bacterial community because it has been shown that only about $1 \%$ of the total number of actively respiring bacterial cells can be cultured on laboratory media (Ward et al. 1992; Amann et al. 1995).
Application of molecular methods in environmental microbiology has made it possible to study microbial communities in soils in new approaches. These techniques are based on the extraction of genomic DNA directly from soil samples by different methods (Torsvik et al. 1990; Picard et al. 1992; Tsai \& Olson 1992; Zhou et al. 1996; Miller et al. 1999), the amplification of $16 \mathrm{~S}$ rDNA fragments using universal, domain or groupspecific primers by polymerase chain reaction (PCR) (Myuzer et al. 1993), and the separation of 16S rDNA fragments of different bacteria in different ways, such as Single Strand Conformation Polymorphism (SSCP) (Frank \& Christoph 1998), Terminal Restriction Fragment Length Polymorphism (T-RFLP) (Thomas et al. 2000), Amplified Ribosomal DNA Restriction Analysis (ARDRA) (James et al. 1999) and Denaturing Gradient Gel Electrophoresis (DGGE) (Muller et al. 2002). Among these methods for separation of DNA fragments, DGGE has been widely used in recent years, following its first use to study a microbial community in 1993 (Myuzer et al. 1993).

The aim of the present study was to determine the impact of the application of fenvalerate on the genetic diversity and the diversity of the cultivable heterotrophic fraction (hereafter referred to as heterotrophic diversity) of the bacterial community in soil. Genetic diversity was analysed by total DNA extraction, PCR amplification of 
<smiles>CC(C)C(C(=O)OC(C#N)c1ccc(Cl)cc1)c1ccccc1</smiles>

Figure 1. Structure of fenvalerate.

16S rDNA fragments followed by separation by DGGE. Two approaches were taken to measure the diversity of the heterotrophic population: (i) colony shape, size, colour, etc., and (ii) colony appearance where isolates are grouped according to the time of appearance on solid media. Fenvalerate at concentrations of $0.1,0.5$ and $1.0 \mathrm{mg} \mathrm{g}^{-1}$ soil was used as stressor in this experiment.

\section{Materials and methods}

\section{Soil samples and fenvalerate treatments}

The soil used was an agricultural soil without a history of fenvalerate application. It was collected in February of 2003 in ShaanXi province of China and stored at $4{ }^{\circ} \mathrm{C}$ until used. Soil characteristics were total C $1.53 \%$; total $\mathrm{N} 0.094 \%$; $\mathrm{C} / \mathrm{N}$ ratio 16.28 ; sand $26.68 \%$; silt $59.16 \%$; clay $14.16 \%$; water-holding capacity $15.27 \%$; pH 8.02 . Technical grade fenvalerate was applied to triplicate soil samples (100 g each) at $0.1,0.5$ and $1.0 \mathrm{mg}$ fenvalerate $\mathrm{g}^{-1}$ of dry soil. Soil samples used were coded as follow: soil A $\left(0.1 \mathrm{mg} \mathrm{g}^{-1}\right)$, soil $\mathrm{B}\left(0.5 \mathrm{mg} \mathrm{g}^{-1}\right)$, and soil $\mathrm{C}$ $\left(1.0 \mathrm{mg} \mathrm{g}^{-1}\right)$ and soil $\mathrm{D}$ (control sample). They were incubated at $25{ }^{\circ} \mathrm{C}$ and supplements of sterile water were supplied every 3 days to keep the water concentration constant. Genetic analysis by PCR-DGGE was performed at intervals of 10 days and the diversity were analysed after a 40 -day incubation at $25^{\circ} \mathrm{C}$.

\section{Enumeration and morphological examination of colony-forming units (c.f.u.)}

Hundred microlitre of appropriate soil dilutions were spread on LB agar plates supplemented with fungicide

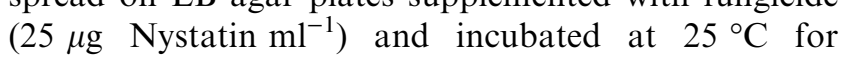
14 days. Fenvalerate-resistant c.f.u. were enumerated on similar plates also containing $0.5 \mathrm{mg}$ fenvalerate $\mathrm{ml}^{-1}$. Visible colonies were enumerated and marked daily throughout the incubation period. For typing of colony morphology on non-selective and fenvalerateresistant LB plates, the 30-100 colonies that had developed on each plate after 4-5 days of incubation at $25^{\circ} \mathrm{C}$ were grouped into morphotypes on the basis of visual characteristics such as colony colour, diameter, edge, surface and other special characteristics (Simbert \& Krieg 1994). All morphological examinations were made on three replicate samples of each soil.

\section{Soil DNA extraction, purification and PCR-DGGE}

A previously published extraction method (Zhou et al. 1996) was used to extract the genomic DNA of soil samples in this study. Silver Bead DNA Gel Recovery Kit (manufactured by Shang Hai Sangon Co. Ltd.) was used to purify the crude genomic DNA. The partial bacterial 16S rRNA genes (16S rDNA fragments which are about $230 \mathrm{bp}$ ) were amplified with the forward primer $F_{357}$ (5'-CCT ACG GGA GGC AGC AG-3') and the reverse primer $\mathrm{R}_{518}\left(5^{\prime}\right.$-ATT ACC GCG GCT GCT GG-3') (Myuzer et al. 1993). As forward primer, a 40-base GC clamp (5'-CGC CCG CCG CGC GCG GCG GGC GGG GCG GGG GCA CGG GGG G-3') was added in $5^{\prime}$ end to stabilize the melting behaviour of the DNA fragments. PCR cycling was performed with Applied Biosystem Gene Amp PCR system 2700. The temperature cycling conditions were as previously described (Myuzer et al. 1993). After purification of the amplified DNA fragments by Silver Bead DNA Gel Recovery Kit (manufactured by Shang Hai Sangon Co. Ltd.), the DGGE was carried out using a DCode ${ }^{\mathrm{TM}}$ Universal Detection System according to the manufacture's instructions (Bio-Rad). The wells were loaded with $25 \mu \mathrm{l}$ of amplified DNA products, and electrophoresis was performed in $10 \%(\mathrm{w} / \mathrm{v})$ acrylamide gels with a linear gradient of the denaturants (urea and formamide) from 30 to $50 \%$ at $60{ }^{\circ} \mathrm{C}$ for $5 \mathrm{~h}$ at $120 \mathrm{~V}$. Gels were stained in an ethidium bromide solution and photographed with a YLN-2000 Gel Analysis System (YLN, China).

\section{$D G G E$ band image analysis}

For each lane in DGGE gels, band patterns and average intensities of individual bands were analysed using Quantity One image analysis software, Version 4.0 (BioRad laboratories). The software recorded each band's position and average intensity relative to the cumulative intensity value of all bands in the given lane. A band of DNA was detected if it accounted for more than $0.2 \%$ of the total lane intensity.

\section{$16 S$ rRNA gene sequence determination and accession numbers}

DGGE bands that appeared visually to be enhanced or inhibited in DGGE images were excized, eluted in $100 \mu \mathrm{l}$ water, re-amplified as described above, and electrophoresed with DGGE. Band excision, PCR and DGGE were repeated until a single band was present. For cloning and sequencing, PCR products generated from DGGE bands were amplified using the above primers, ligated into pUCm-T vector (ShangHai Sangon, China) and transformed into Escherichia coli DH5- $\alpha$. Sequences 
were determined using the Thermo Sequence fluorescent labelled primers cycle sequencing kit and a Pharmacia ALF express automated sequencer. The partial $16 \mathrm{~S}$ rRNA gene sequences recovered from the fenvaleratetreated soils have been deposited in the Genebank database under accession numbers AY298737, AY298740, AY298741, AY308875 and AY308876.

\section{Diversity of colony-forming population and genetic diversity}

When analysing cultivable heterotrophic and genetic diversity, Richness $(S)$, Shannon-Wiener $(S-W)$ indices $(H)$ and Evenness $\left(E_{H}\right)$ were used according to the following equations:

$$
\begin{aligned}
& H=-\sum_{i=1}^{S} p_{i} \ln p_{i}=-\sum_{i=1}^{S}\left(N_{i} / N\right) \ln \left(N_{i} / N\right) \\
& E_{H}=H / H_{\max }=H / \ln S
\end{aligned}
$$

where $p_{\mathrm{i}}$ is the ratio between the number in a specific group and the total number, $S$ is the total number of morphotypes in cultivable heterotrophic diversity and $p_{\mathrm{i}}$ is the ratio between the specific band intensity and the total intensity of all bands, $S$ is the total number of bands in each samples in genetic diversity.

\section{Results}

\section{Effect of fenvalerate on the microbial populations}

After treatment with different rates of fenvalerate, the number of heterotrophic bacteria capable of forming colonies of four soil samples on solid medium was enumerated on both non-selective and fenvalerate-resistant LB agar plates (Table 1). The total cultivable. c.f.u. on non-selective LB agar plates increased from $6.0 \times 10^{6}$ to $11.0 \times 10^{6}$ with the concentration of treated pesticide (fenvalerate) in soils increased from 0 to $1.0 \mathrm{mg} \mathrm{g}^{-1}$. The fenvalerate-resistant c.f.u. showed the same tendency.

The appearance of colonies on non-selective and fenvalerate-resistant agar plates over a 14-day period revealed that in all soil samples most of the colonies

Table 1. The total cultivable c.f.u. and the fenvalerate-resistant c.f.u. of different soil samples after application of fenvalerate for 40 days.

\begin{tabular}{llll}
\hline Soil & \multicolumn{2}{l}{ Mean $\pm \mathrm{SD}$} & \\
\cline { 2 - 3 } & $\left.\begin{array}{l}\text { Total } \\
\left(10^{6} \text { c.f.u. g dw soil }\right.\end{array}{ }^{-1}\right)$ & $\begin{array}{l}\text { Fenvalerate-resistant } \\
\left(10^{6} \text { c.f.u. g dw soil }\right.\end{array}$ & \\
& & $\begin{array}{l}\text { Fenvalerate- } \\
\text { resistant } \\
(\% \text { of total })\end{array}$ \\
\hline A & $6.3 \pm 0.2$ & $2.3 \pm 0.1$ & 36.4 \\
B & $7.7 \pm 0.3$ & $5.3 \pm 0.2$ & 68.5 \\
C & $11.0 \pm 0.3$ & $9.9 \pm 0.3$ & 90.4 \\
D & $6.0 \pm 0.2$ & $1.9 \pm 0.1$ & 31.6 \\
\hline
\end{tabular}

appeared within a few days of plating (Figure 2A, B). Obviously, most of the c.f.u. on these non-selective plates appeared in the first day, while the fenvalerateresistant c.f.u. in soil A, soil B, soil C and soil D were in the first, first, second and third day of plating respectively, which showed that most of the fenvalerateresistant c.f.u. appeared after acclimatizing themselves to the rich fenvalerate conditions for different days according to the different fenvalerate treatment rates.

\section{Diversity of the colony-forming populations}

The diversity of the cultivable heterotrophic fraction of the bacterial community was examined according to colony morphological difference, e.g., colour, shape, size, etc., on both non-selective and fenvalerate-resistant LB agar plates. Diversity analysis based on colony morphology (Table 2) showed that an obvious decrease in the diversity of the total cultivable c.f.u. in the fenvalerate treated soils compared to the control soil, while the diversity of fenvalerate-resistant c.f.u. in the treated soils (soil A, B and C) decreased with rate of $0.1 \mathrm{mg}$ fenvalerate $\mathrm{g}^{-1}$ soil and increased with fenvalerate from 0.5 to $1.0 \mathrm{mg} \mathrm{g}^{-1}$ soil, which was likely due to the different response of the bacterial community to the environmental stress caused by fenvalerate. Additionally, for each soil sample, the diversity of total cultivable c.f.u. was more complex than that of the fenvalerateresistant c.f.u. since not all the total cultivable c.f.u. could resist the environmental stress.

\section{Genetic diversity analysis}

Table 3 shows that the genetic diversity of the treated soils also decreased compared to the control soil, and that with the increased fenvalerate application, the genetic diversity showed a small increase. Although the genetic diversity varied like the diversity of the c.f.u., the values of richness $\left(E_{H}\right)$ and Shannon-Wiener index $(H)$ of each soil were obviously bigger than those in diversity of c.f.u. The difference between the diversity of c.f.u. and the genetic diversity for the same soil showed that different analysis methods could give the different results in analysing the bacterial diversity, and comprehensive results could be achieved by using the molecular techniques. This conclusion agreed with previous findings (Ward et al. 1992; Amann et al. 1995).

\section{$D G G E$ band analysis}

As evidenced by the number of DNA bands detected in the control lanes of the denaturing gradient gels (Figure 3), the 12 different treated soils and 4 control soils displayed abundant bacterial communities. Many of the DGGE bands were unique to each of the different treated soils, suggesting that the treatment with fenvalerate could change the habitat of the soils and that some unique bacteria were forced to adapt themselves and exist in the changed habitat. Additionally, there were 

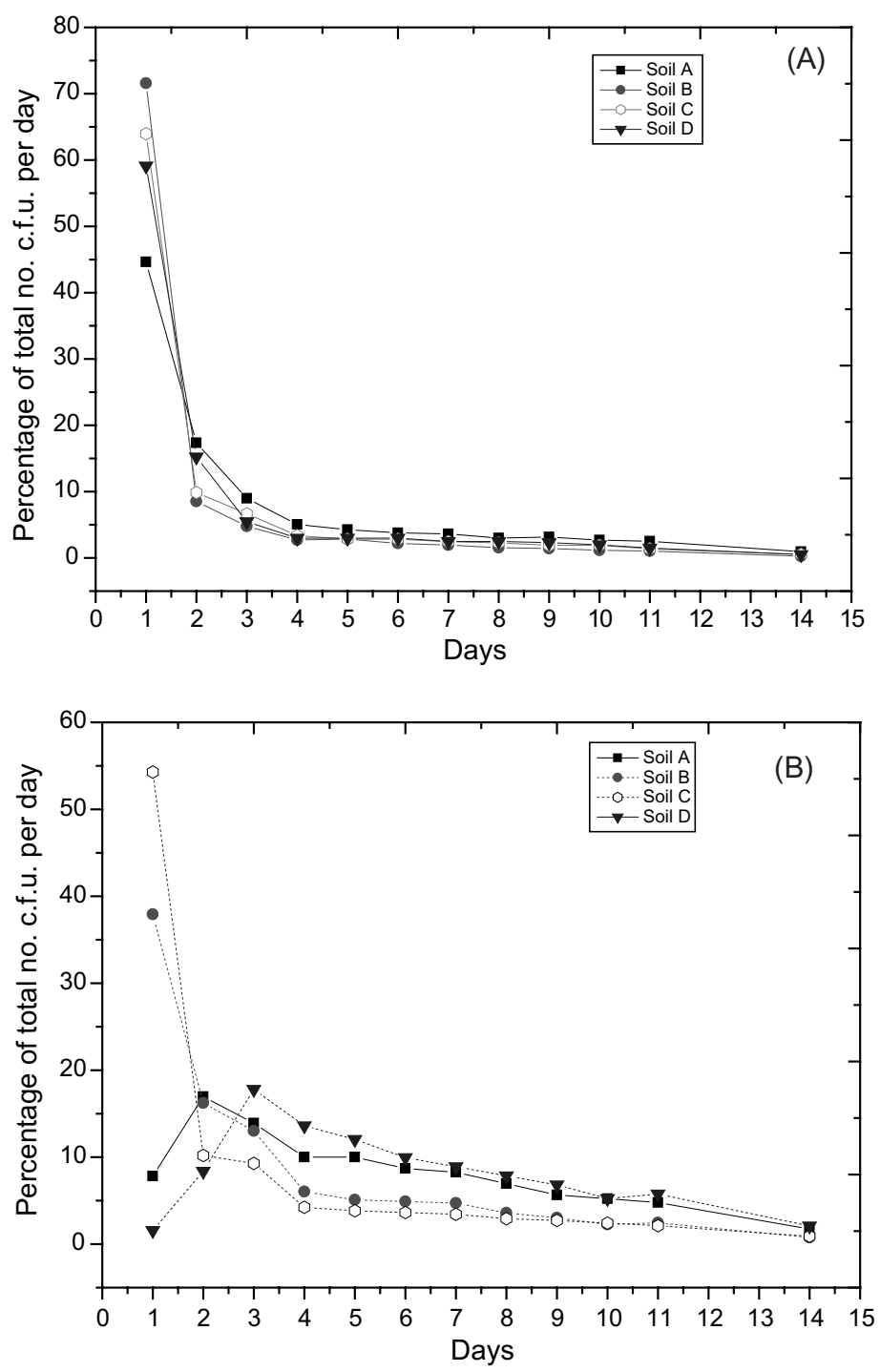

Figure 2. (A) Colony appearance on non-selective agar plates each day during a 14-day period expressed as percentage of the total number of c.f.u. (B) Colony appearance on fenvalerate-resistant agar plates each day during a 14-day period expressed as percentage of the total number of c.f.u.

Table 2. Shannon-Wiener index $(H)$, richness $(S)$ and evenness $\left(E_{H}\right)$ $[$ mean \pm SEM] of each soil samples estimated by the shapes of random 100 clones on non-selective and fenvalerate-resistant agar plates after application of fenvalerate for 40 days.

\begin{tabular}{llll}
\hline Soil & \multicolumn{3}{l}{ Mean $\pm \mathrm{SD}$} \\
\cline { 2 - 4 } & $\begin{array}{l}\text { Shannon-Wiener } \\
\text { index }(H)\end{array}$ & Richness $(S)$ & Evenness $\left(E_{H}\right)$ \\
& $0.4 \pm 0.0$ & $3.2 \pm 0.1$ & $0.4 \pm 0.0$ \\
\hline $\mathrm{A}(\mathrm{r})^{\mathrm{a}}$ & $0.9 \pm 0.1$ & $5.3 \pm 0.1$ & $0.6 \pm 0.0$ \\
$\mathrm{~A}(\mathrm{n})^{\mathrm{b}}$ & $0.8 \pm 0.1$ & $3.1 \pm 0.1$ & $0.8 \pm 0.1$ \\
$\mathrm{~B}(\mathrm{r})$ & $1.1 \pm 0.2$ & $4.7 \pm 0.2$ & $0.8 \pm 0.1$ \\
$\mathrm{~B}(\mathrm{n})$ & $0.7 \pm 0.1$ & $2.7 \pm 0.1$ & $0.7 \pm 0.0$ \\
$\mathrm{C}(\mathrm{r})$ & $1.3 \pm 0.2$ & $4.2 \pm 0.1$ & $1.0 \pm 0.1$ \\
$\mathrm{C}(\mathrm{n})$ & $0.6 \pm 0.1$ & $3.4 \pm 0.2$ & $0.6 \pm 0.0$ \\
$\mathrm{D}(\mathrm{r})$ & $1.6 \pm 0.2$ & $6.5 \pm 0.1$ & $0.9 \pm 0.1$ \\
$\mathrm{D}(\mathrm{n})$ & & & \\
\hline
\end{tabular}

a (r) represents the fenvalerate-resistant agar plates.

b (n) represents the non-selective agar plates.

several similarities in banding position among the soils that received different fenvalerate amounts and different periods of treatment, indicating that many common
Table 3. Shannon-Wiener index $(H)$, richness $(S)$ and evenness $\left(E_{H}\right)$ of each soil sample estimated by the DGGE band patterns.

\begin{tabular}{llrl}
\hline Soil & $\begin{array}{l}\text { Shannon-Wiener } \\
\text { index }(H)\end{array}$ & Richness $(S)$ & Evenness $\left(E_{H}\right)$ \\
\hline A & 1.90 & 11 & 0.77 \\
B & 1.96 & 8 & 0.94 \\
C & 2.06 & 13 & 0.80 \\
D & 2.69 & 21 & 0.88 \\
\hline
\end{tabular}

microbial members were still present in each soil regardless of the treatments. Some bacterial band intensities were enhanced when the soil was treated with fenvalerate for 40 days, and other dominant bands in DGGE displayed in the treated soils with 10, 20 and 30day incubation disappeared in soils with 40-day incubation, which revealed that some bacteria could not survive the long-time exposure to fenvalerate. The dominant bands in the soils of 40-day samples were likely to be the fenvalerate-resistant bacteria. Therefore, 


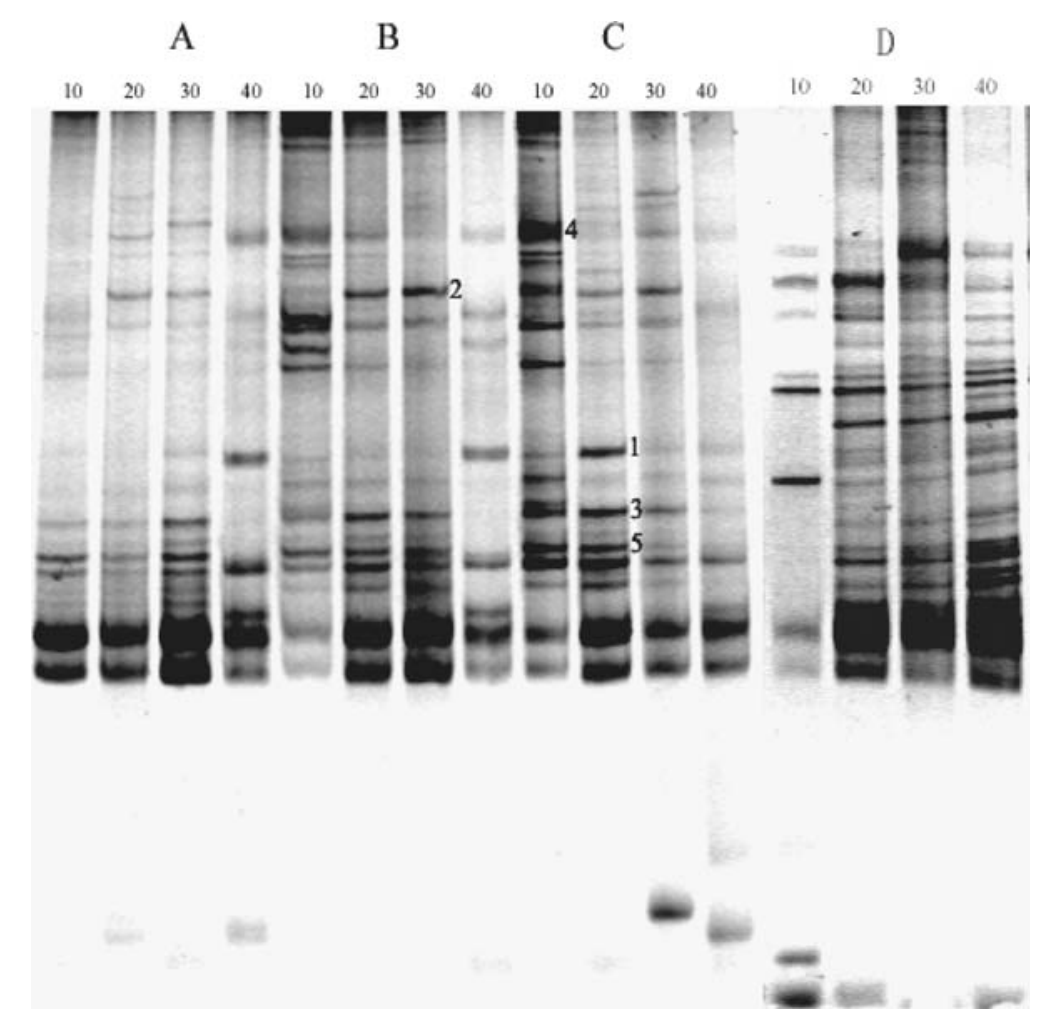

Figure 3. DGGE profiles of different treatment soil samples.

the appearance of those fenvalerate-resistant bacteria was directly or indirectly due to the combinations of the amounts of fenvalerate and the treatment periods.

\section{Nucleotide sequencing and analysis}

PCR-DGGE of amplified 16S rRNA genes from the treated soils resulted in five bacterial bands being excized for sequence analysis. Comparison of our cloned sequences with published sequences in the NIH Genebank database resulted in similarity ranging from 96 to $100 \%$ (Table 4). The sequence of cloned DNA derived from excized bands was most similar to organisms in the Pseudomonas genus (bands 2-5) and Xanthomonas campestris or Streptomyces avermitilis (band 1). However, since the DNA fragments being sequenced were, apparently, too small to give a true idea of the identity of the originating bacterium, each band represented different species with the same and high levels of similarity.

\section{Discussion}

Effect of fenvalerate application on the existing bacterial community in agricultural soil was observed in the two types of diversity investigated in this study. The cultivable heterotrophic fraction of the community investigated by the cultivation-based method in the laboratory represented a lower percentage of the whole community, while newly developed molecular techniques (such as PCR-DGGE) could analyse most of the whole community. The cultivation-based methods provided the visual colonies of a few dominant bacteria in the whole community and gave more direct information about these bacteria, while the genetic information of most bacteria in the community could be reflected by the molecular techniques. Hence, combination of the traditional methods and the molecular techniques was the best choice to study the community in environmental samples.

The diversity analysis of the cultivable heterotrophic population showed that the diversity of the total population decreased due to the fenvalerate stress, but the diversity of the fenvalerate-resistant population increased at suitable application rates $(0.5$ soil and $1.0 \mathrm{mg} \mathrm{g}^{-1}$ soil) of fenvalerate (Table 2). The total cultivable c.f.u. and the fenvalerate-resistant c.f.u. also increased with increasing application of fenvalerate (Table 1), possibly because application of fenvalerate could stimulate the growth of these c.f.u. to some extent. The diversity of the fenvalerate-resistant c.f.u. surprisingly tended to be higher than that of the control soil with fenvalerate at 0.5 soil and $1.0 \mathrm{mg} \mathrm{g}^{-1}$ soil (Table 2), possibly because the long exposure to these fenvalerate rates, most of the c.f.u. adapt themselves to survive in the pesticide.

The effect of fenvalerate on genetic diversity was reflected by bands in DGGE directly with decreases observed in all treated soils compared to the control soil (Table 3). With increasing of addition of fenvalerate to 
Table 4. Phylogenetic relationship of bands sequenced in the study.

\begin{tabular}{|c|c|c|c|c|c|}
\hline $\begin{array}{l}\text { Band (Genebank } \\
\text { accession number) }\end{array}$ & $\begin{array}{l}\text { Number of } \\
\text { bp sequenced }\end{array}$ & Kingdom & $\begin{array}{l}\text { Phylogenetic } \\
\text { group }^{\text {a }}\end{array}$ & $\begin{array}{l}\text { Closed unidentified relative } \\
\text { (Genebank accession number) }\end{array}$ & Identity $(\%)$ \\
\hline \multirow[t]{2}{*}{$\begin{array}{l}\text { Band } 1 \\
(\text { AY308876) }\end{array}$} & \multirow[t]{2}{*}{210} & \multirow[t]{2}{*}{ Bacteria } & $\gamma$-Proteobacteria & $\begin{array}{l}\text { Xanthomonas campestris } \\
\text { (AE012366.1) }\end{array}$ & 100 \\
\hline & & & Actinobacteria & $\begin{array}{l}\text { Streptomyces avermitilis } \\
(\mathrm{AP} 005031.1)^{\mathrm{b}}\end{array}$ & 100 \\
\hline \multirow[t]{4}{*}{$\begin{array}{l}\text { Band } 2 \\
(\text { AY308875) }\end{array}$} & \multirow[t]{4}{*}{213} & \multirow[t]{4}{*}{ Bacteria } & \multirow[t]{4}{*}{$\gamma$-Proteobacteria } & $\begin{array}{l}\text { Pseudomonas stutzeri } \\
\text { (U58661.1) }\end{array}$ & 96 \\
\hline & & & & $\begin{array}{l}\text { Pseudomonas alcaligenes } \\
\text { (AY269255.1) }\end{array}$ & 96 \\
\hline & & & & $\begin{array}{l}\text { Pseudomonas putida } \\
\text { (AF509331.1) }\end{array}$ & 96 \\
\hline & & & & $\begin{array}{l}\text { Pseudomonas migulae } \\
\text { (AF321026.1) }\end{array}$ & 96 \\
\hline \multirow[t]{3}{*}{$\begin{array}{l}\text { Band } 3 \\
(\text { AY298740) }\end{array}$} & \multirow[t]{3}{*}{208} & \multirow[t]{3}{*}{ Bacteria } & \multirow[t]{3}{*}{$\gamma$-Proteobacteria } & $\begin{array}{l}\text { Pseudomonas reactans } \\
\text { (AY277894.1) }\end{array}$ & 97 \\
\hline & & & & $\begin{array}{l}\text { Pseudomonas putida } \\
\text { (AF321023.1) }\end{array}$ & 97 \\
\hline & & & & $\begin{array}{l}\text { Pseudomonas pavonanceae } \\
\text { (AY136082.1) }\end{array}$ & 97 \\
\hline \multirow[t]{4}{*}{$\begin{array}{l}\text { Band } 4 \\
(\text { AY298741) }\end{array}$} & \multirow[t]{4}{*}{195} & \multirow[t]{4}{*}{ Bacteria } & \multirow[t]{4}{*}{$\gamma$-Proteobacteria } & $\begin{array}{l}\text { Pseudomonas putida } \\
\text { (AF509331.1) }\end{array}$ & 100 \\
\hline & & & & $\begin{array}{l}\text { Pseudomonas migulae } \\
\text { (AF321026.1) }\end{array}$ & 100 \\
\hline & & & & $\begin{array}{l}\text { Pseudomonas alcaligenes } \\
\text { (AF406655.1) }\end{array}$ & 100 \\
\hline & & & & $\begin{array}{l}\text { Pseudomonas stutzeri } \\
\text { (AF307873.1) }\end{array}$ & 100 \\
\hline \multirow[t]{4}{*}{$\begin{array}{l}\text { Band } 5 \\
\text { (AY298737) }\end{array}$} & \multirow[t]{4}{*}{188} & \multirow[t]{4}{*}{ Bacteria } & \multirow[t]{4}{*}{$\gamma$-Proteobacteria } & $\begin{array}{l}\text { Pseudomonas putida } \\
\text { (AF509331.1) }\end{array}$ & 99 \\
\hline & & & & $\begin{array}{l}\text { Pseudomonas migulae } \\
\text { (AF321026.1) }\end{array}$ & 99 \\
\hline & & & & $\begin{array}{l}\text { Pseudomonas alcaligenes } \\
\text { (AF406655.1) }\end{array}$ & 99 \\
\hline & & & & $\begin{array}{l}\text { Pseudomonas stutzeri } \\
\text { (AF307873.1) }\end{array}$ & 99 \\
\hline
\end{tabular}

a $\alpha$, alpha; $\gamma$, gamma.

$\mathrm{b}$ The accession number in DDBJ database.

soils, some bands in DGGE disappeared, and the genetic diversity slowly decreased. Some population of weakly resistant or non-resistant could not survive the heavy selective pressure and long time treatment caused this to happen.

Few studies have used the Shannon-Wiener $(S-W)$ indices $(H)$ to describe the soils treated in this way and provide a numerical indicator to compare changes in the structure of dominant members in the microbial community. Since $H$ is based on the summed proportional abundance of individual bacterial types (DGGE bands and their intensity), a decrease in $H$ in soils treated with fenvalerate at different amounts reflected the impact of this pesticide on the bacterial community, which caused the decrease in the number of bacterial types (bands) or a decrease in the proportional abundance of a given type (band intensity). The genetic diversity indices were based partially on the intensity of bands in DGGE fingerprints and relied on the assumption that band intensity was related to initial DNA template amount in the extracted sample, and thus, the original population size. Although biases are often associated with PCR-amplification of mixture of DNA templates (Suzuki \& Giovannoni 1996), band intensity will often related to initial cell numbers (Gelsomino et al. 1999) and has been frequently relate to relative dominant phylotype abundance (Konopka et al. 1999). Hence, the results of genetic diversity analysed by DGGE bands and their intensity were realistic to some extent.

The comparison of excized band sequences to those published in the Genebank database (Table 4) suggested that the impact of the pesticide treatments was not confined to any one group of bacteria. Sequencing revealed that the bacteria affected by the fenvalerate treatment were most similar to members of Pseudomonas genus (Pseudomonas stutzeri, Pseudomonas alcaligenes, Pseudomonas putida or Pseudomonas migulae) (band 2 to band 5 similarity from 96 to 100\%) and Xanthomonas campestris or Streptomyces avermitilis (band 1 similarity with $100 \%$ ). Thus, it is clear that the application of fenvalerate in soil can impact many of the bacteria and allow some specific bacteria exist in the treated soils. 


\section{Acknowledgements}

This work is a part of the National Science and Technology Key Project " Study of new technology of ecology evaluation to soil resource of country." (No. 2001BA903B). We thank Mrs Jingfang Sun for providing us PCR and DGGE instruments.

\section{References}

Amann, R.I., Wolfgang, L. \& Schleifer, K.H. 1995 Phylogenetic identification and in situ detection of individual microbial cells without cultivation. Microbiological Reviews 59, 143-169.

Frank, S. \& Christoph, C.T. 1998 A new approach to utilize PCR single strand conformation polymorphism for $16 \mathrm{~S}$ rRNA genebased microbial community analysis. Applied and Environmental Microbiology 64, 4870-4876.

Gelsomino, A., Keijzer-Wolter, A.C., Cacco, G. \& van Elsas, J.D 1999 Assessment of the bacterial community structure in soil by polymerase chain reaction and denaturing gradient gel electrophoresis. Journal of Microbiological Methods 38, 1-15.

James, M.T., Stella, A.-B., Laus, N., Terry, L.M. \& Shannkn, J.F. 1999 Open the black box of soil microbial diversity. Applied Soil Ecology 13, 109-122.

Konopka, A., Bercot, T. \& Nakatsu, C. 1999 Bacterioplankton community diversity in a serious of thermally stratified lakes. Microbial Ecology 38, 126-135.

Miller, D.N., Bryant, J.E., Madsen, E.L. \& Ghiorse, W.C. 1999 Evaluation of DNA extraction and purification procedures for soil and sediment samples. Applied and Environmental Microbiology $\mathbf{6 5}$, $4715-4724$
Muller, A.K., Westergaard, K., Christensen, S. \& Sorensen, S.J. 2002. The diversity and function of soil microbial communities exposed to different disturbances. Microbial Ecology 44, 29-58.

Myuzer, G., Ellen, C.D.W. \& Andre, G.U. 1993 Profiling of complex microbial populations by denaturing gradient gel electrophoresis analysis of polymerase chain reaction genes coding for $16 \mathrm{~S}$ rRNA. Applied and Environmental Microbiology 59, 695-700.

Picard, C., Ponsonnet, C., Paget, E., Nesme, X. \& Simonet, P. 1992 Detection and enumeration of bacterial in soil by direct DNA extraction and polymerase chain reaction. Applied and Environmental Microbiology 58, 2712-2722.

Simbert, R.M. \& Krieg, N.R. 1994 Phenotypic characterization. In Methods for General and Molecular Bacteriology, eds. Gerhardt, P., Murray, R.G.E., Wood, W.A. \& Krieg, N.R. pp. 607-615. Washington, DC, USA: American Society for Microbiology, (ISBN: 1555810489).

Suzuki, M.T. \& Giovannoni, S.J. 1996 Bias caused by template annealing in the amplification mixtures of $16 \mathrm{~S}$ rRNA genes by PCR. Applied and Environmental Microbiology 62, 1405-1415.

Thomas, L., Peter, F.D. \& Werner, L. 2000 Use of the T-RFLP technique to assess spatial and temporal changes in the bacterial community structure within an agricultural soil planted with transgenic and non-transgenenic potato plants. FEMS Microbiology Ecology 32, 241-247.

Torsvik, V., Goksøyr, J. \& Daae, F.L. 1990 High diversity in DNA of soil bacterial. Applied and Environmental Microbiology 56, 782-787.

Tsai, Y. \& Olson, B.H. 1992 Rapid method for separation of bacterial DNA from humic substances in sediments for polymerase chain reaction. Applied and Environmental Microbiology 58, 2292-2295.

Ward, D.M., Bateson, M.M., Weller, R. \& Ruff-Roberts, A.L. 1992 Ribosomal RNA analysis of microorganisms as they occur in nature. Advances in Microbial Ecology 12, 220-286.

Zhou, J., Bruns, M.A. \& Tiedje, J.M. 1996 DNA recovery from soils of diverse composition. Applied and Environmental Microbiology 62, $316-322$. 